\title{
Õpetajakoolituse üliõpilaste teadmiste, arusaamade, emotsioonide ja kogemuste avaldumine erivajadusi käsitlevates esseedes
}

\author{
Krista Uibu $^{\text {al }}$, Helin Puksand ${ }^{\mathrm{b}}$ \\ ${ }^{a}$ Tartu Ülikooli haridusteaduste instituut \\ ${ }^{b}$ Tallinna Ülikooli haridusteaduste instituut
}

\begin{abstract}
Annotatsioon
Kaasava hariduse põhimõtte järgi on oluline, et õpetaja märkaks õpetamisel laste hariduslikke erivajadusi ja varieeriks nende järgi õpetamist. See, kuivõrd on õpetaja valmis õpetama erivajadusega õpilast, sõltub muu hulgas tema teadmistest, arusaamadest ja kokkupuutest erivajadusega. Artikli eesmärk on välja selgitada, kuidas õpetajakoolituse üliópilased kirjeldavad oma teadmisi, arusaamu, emotsioone ja kogemusi seoses erivajadustega. Valimisse kuuluvad kahe ülikooli 218 üliõpilast, kes lugesid erivajadusi käsitlevaid raamatuid ja kirjutasid selle põhjal temaatilise essee. Esseede analüüsimisel kombineeritakse induktiivset sisuanalüüsi ja konfiguratsioonilist sagedusanalüüsi. Rühma keskmiste tulemuste tasandil ilmneb, et üliõpilased kirjeldavad intellekti- ja liikumispuudeid mitmekesiselt, seevastu omi kogemusi käitumishäirete ja düsleksiaga väljendavad nad ühekülgsemalt. Indiviiditasandi analüüsidest nähtub, et liikumispuude mitmekülgsem kirjeldus võib tuleneda üliõpilaste kogemusest selle erivajadusega. Uurimistulemustest selgub ka, et oodatust rohkem on neid üliõpilasi, kes kirjeldavad ühelaadselt autismiga seotud emotsioone. Et kaasava hariduse idee rakenduks kooliharidussüsteemis, on oluline kujundada tulevaste õpetajate arusaamu, pöörates õpetajakoolituses sellele varasemast suuremat tähelepanu.
\end{abstract}

Võtmesõnad: õpetajakoolitus, erivajadused, arusaamad, kogemused, temaatiline essee 


\section{Sissejuhatus}

Eestis lähtutakse kaasava hariduse põhimõttest, mille kohaselt õpivad kergemate erivajadustega lapsed üldjuhul elukohajärgses tavakoolis (Haridus- ja Teadusministeerium, 2016). See seab igale õpetajale nõude, et ta peab tundma erivajadusi ja nende tunnuseid, sest kaasava hariduse elluviimisel on määrav roll hästi ettevalmistatud õpetajal ning tema positiivsel suhtumisel (Gafoor \& Asaraf, 2009; Häidkind \& Oras, 2016; Lambe, 2007; Meynert, 2014; Specht et al., 2016). Rahvusvahelisest õpetamise ja õppimise uuringust TALIS selgus, et Eesti koolijuhid peavad kõige suuremaks probleemiks erivajadustega laste õpetamiseks vajalike oskustega õpetajate puudust: koguni $61 \%$ õpetajatest töötab koolides, mille direktor väidab, et õpetajate vähesed teadmised erivajadustest piiravad kooli võimekust hästi õpetada (Übius, Kall, Loogma, \& Ümarik, 2014). See omakorda seab ülikoolidele ülesande valmistada ette õpetajaid, kes tunnevad ära erivajadused ja oskavad erivajadustega lapsi õpetada.

Häidkind ja Oras (2016) järeldavad oma uurimuses, et kaasava hariduse põhimõtete arendamiseks peaksid õpetajad ära tundma erivajaduste liike, kuid peale äratundmise on vajalik valmisolek tegelda konkreetsete óppimisja käitumisprobleemidega. Edukas kaasamine on rajatud arusaamale, et inimesed on erinevad (Vuran, 2014), seetõttu peab õpetaja teadma, missugune on lapse eakohane areng ja mis tunnused viitavad erivajadusele. Valmisolekut kaasata mõjutavad aga eelkõige õpetajate hoiakud ja arusaamad (Abu-Hamour \& Muhaidat, 2013; Norwich, 2002). Õpetajate hoiak kaasamise suhtes oleneb laste vanusest ja halveneb üldjuhul õppija vanuse kasvades: lasteaiaõpetajate suhtumine erivajadustega õppijate kaasamisse on valdavalt positiivne, algklassiõpetajate suhtumine aga neutraalne või isegi negatiivne (Häidkind \& Oras, 2016). Samas suhtuvad esimese kooliastme õpetajad kaasamisse positiivsemalt kui teise ja kolmanda kooliastme omad (DeSimone \& Parmar, 2006; Eha, 2010).

Õpetajaid ja õpetajaks õppivaid üliõpilasi ning erivajaduste teemat on uuritud nii Eestis kui ka mujal maailmas eri meetoditega. Testitud on teadmisi (Seepter, 2010), hoiakuid ja käitumismustreid (Levins, Bornholt, \& Lennon, 2005). Küsimustikega on uuritud emotsioone (Kikas \& Timoštsuk, 2016), hoiakuid (Ting \& Gilmore, 2012) ning kogemusi erivajadustest (Gehrke, Cocchiarella, Harris, \& Puckett, 2014). Enamik neist uuringuist keskendub ühele või kahele erivajaduste aspektile (nt teadmised ja emotsioonid), kuid selliseid uurimusi, kus oleks koos analüüsitud teadmisi, arusaamu ja emotsioone, seni teadaolevalt Eestis tehtud ei ole. Siinse uurimuse eesmärk on välja selgitada, kuidas kirjeldavad üliõpilased omi teadmisi, arusaamu, emotsioone ja kogemusi eri liiki erivajaduste korral. Kuna uurimuse valim on võrdlemisi suur 
$(N=218)$, kasutatakse andmestiku saamiseks temaatilist esseed kui üht tekstipõhist võimalust koguda üksikisikute praktilisi teadmisi, kogemusi ja tõlgendusi ning leida seeläbi seaduspärasused uuritava fenomeni kohta (McAlpine, 2016).

\section{Hariduslikud erivajadused ja nende liigitamine}

Kaasava hariduse kontekstis peab iga õpetaja kõigepealt teadma, kes on haridusliku erivajadusega õpilane. „Hariduse ja kasvatuse sõnaraamatus“ (Maanso et al., 2014) defineeritakse haridusliku erivajadusega õpilast kui õpilast, kelle andekus või, vastupidi, õpiraskused, terviseseisund, puue, käitumis- ja tundeeluhäired või õppekeele ebapiisav valdamine tingib vajaduse teha muutusi või kohandusi õppe sisus ja protsessis, koormuses või õpikeskkonnas. Põhikooli- ja gümnaasiumiseaduses (2010) täpsustatakse, et haridusliku erivajadusega õpilase erivajadus toob kaasa vajaduse muuta õppevahendeid ja -ruume, suhtluskeelt ning võtta tööle tugipersonal ja spetsiaalse ettevalmistusega õpetajad.

Traditsiooniliselt liigitatakse erivajadusi tekkepõhjuste ja avaldumise eripärast lähtudes, eristades meele-, intellekti-, kõne- ja kehapuudeid, õpi- ning emotsionaal- või käitumisraskusi (Kirk, Gallagher, \& Anastasiow, 2003). Erivajadusi võib liigitada ka nende raskusastme ja leviku alusel (Kõrgesaar, 2002) ning jagada need nähtavateks ja nähtamatuteks. Nähtava erivajaduse tunneb ära väliste tunnuste ja abivahendite järgi (Carter \& Spencer, 2006), nt liikumispuudega inimene kõnnib teisiti või on ratastoolis, vaegkuuljal on näha kuuldeaparaat või vaegnägija käes on valge kepp. Nähtamatu erivajadus on selline, mida ei ole võimalik inimesele otsa vaadates tuvastada ja mis vajab tuvastamiseks pikemaajalist uurimist, nt õpi- ning emotsionaalsed ja käitumisraskused (Black, 2004; Carter \& Spencer, 2006; Olney \& Kim, 2001). Erivajaduste jagunemine nähtavaks ja nähtamatuks tingibki selle, et mõnda erivajadust on raske kindlaks teha (Abu-Hamour \& Muhaidat, 2013).

\section{Õpetajate teadmised, arusaamad, kogemused ja emotsioonid}

On leitud, et kõige positiivsem mõju õpetamisele kaasavas koolis on õpetaja tajutud kompetentsusel ja positiivsel suhtumisel (Lambe, 2007). Kompetentsus hõlmab teadmisi, arusaamu ja kogemusi, suhtumist mõjutavad aga inimese emotsioonid. Õpetajate arusaam, mida on defineeritud kui sõnastamata ja mitteteadvustatud oletusi (Richardson, 1996), mõjutab otseselt õppeprotsessi kvaliteeti (Meynert, 2014). Õpetajad, kellel on positiivsem suhtumine kaasamisse, suudavad erivajadusega õpilastele paremini kohandada ülesandeid ja õppekava, arvestades nende individuaalseid ja erivajadusi (Bhatnagar \& Das, 2014; Swain, Nordness, \& Leader-Janssen, 2012). Positiivset suhtumist kaasavas 
koolis mõjutab sageli aga mure õpetaja enda kompetentsuse pärast, sest õpetaja tunneb end klassis ebakindlalt, kui tal puuduvad teadmised, kuidas erivajadusega last õpetada (Bhatnagar \& Das, 2014; Gafoor \& Asaraf, 2009; Lambe, 2007). Samuti mõjutab negatiivne suhtumine erivajadustesse õpetaja käitumist klassiruumis: õpetajal on erivajadusega lapse suhtes väiksemad ootused, ta alahindab õpilase teadmisi ega pea õpilase toetamist vajalikuks (Čagran \& Schmidt, 2011; Markova, Pit-Ten Cate, Krolak-Schwerdt, \& Glock, 2016).

Mitmed uuringud on näidanud, et õpetaja arusaam kaasavast haridusest sõltub ka erivajaduse liigist (Avramidis, Bayliss, \& Burden, 2000; Čagran \& Schmidt, 2011; Levins et al., 2005). Õpetajad on kergemate erivajaduste suhtes enamasti positiivsemalt meelestatud (Čagran \& Schmidt, 2011), nad on nõus kaasama füüsilise ja meelepuudega ning kergemate õpiraskustega õpilasi, kuid mitte emotsionaal- ja käitumisraskustega lapsi (Hastings \& Oakford, 2003; Levins et al., 2005; Markova et al., 2016). Samas on leitud, et õpetajate ootused meelepuudega, nt kurtide laste suhtes on nii õppimise kui ka käitumise osas väiksemad (Sari, 2007). Paremate teadmistega õpetajad tunnevad seoses erivajadustega vähem negatiivseid emotsioone ning see viib õpilased paremate õpitulemusteni (Kikas \& Timoštsuk, 2016; Sari, 2007).

\section{Erivajaduste käsitlemine õpetajakoolituses}

Ameerika Ühendriikides tehtud uuring näitas, et õpetajate positiivne suhtumine kaasamisse on seotud ülikoolist saadud teadmistega erivajadustest ja kaasavast haridusest (Burke \& Sutherland, 2004). Kui õpetajate ettevalmistuses analüüsitakse rohkem erivajaduste tunnuseid ja erivajadustega õpilaste vajadusi, kujundab koolitus realistlikuma ja positiivsema arusaama erivajadustest, suurendab õpetaja enesekindlust ja tagab seeläbi õpilastele paremad tulemused (Ting \& Gilmore, 2012). Seega peaks õpetajakoolituses olema rõhk teadmistel, mis aitaksid kujundada arusaama erivajadusest mitmel tasandil: erivajaduse avaldumine ja erivajadusega laps ise, tema kasvatamine ja õpetamine ning mõju vanematele ja õpetajatele (Ashby, 2012). Paraku tuleb uuringutest välja, et koolituse läbimine ei taga veel kõigile õpetajatele vajalikke teadmisi. Õpetajakoolituse üliõpilased ja õpetajad ei tunne sageli ära erivajaduste tunnuseid või on nende teadmised lünklikud (Mavropoulou \& Padeliadu, 2000; Ting \& Gilmore, 2012; Toran, Westover, Sazlina, Suziyani, \& Mohd Hanafi, 2016). Seetõttu tuleb mõelda, kuidas tulevasi õpetajaid kõige efektiivsemalt ette valmistada, et kujuneks positiivsem arusaam erivajadustest (Gafoor \& Asraf, 2009).

Õpetajakoolituse ülesanne on pakkuda teadmisi ja kujundada arusaama erivajadustest ja erivajadusega laste õpetamisest (Gafoor \& Asaraf, 2009). Selleks 
on võimalik kasutada mitmeid viise. Kõige tõhusamaks peetakse õppimist praktilise kogemuse kaudu (Shah, Das, Desai, \& Tiwari, 2016), mis suurendab erivajadusest arusaamist ja üliõpilase positiivset suhtumist (Sharma, Forlin, Loreman, \& Earle, 2006; Swain et al., 2012). Teoreetiliste teadmiste saamiseks tuleb üliõpilastel läbi töötada erialast kirjandust, mille valimisel peab arvestama, et artiklites ja õpikutes kõlab professionaalide hääl. Teine võimalus on tutvuda erivajadustega inimlikust vaatenurgast, mida võimaldavad ilukirjandusteosed (Ashby, 2012; Kurtts \& Gavigan, 2008). Selliste teoste lugemine muudab tulevase õpetaja arusaamu, hoiakuid ja emotsioone ning suurendab erivajadustega laste sotsiaalset aktsepteerimist (Vuran, 2014). Kõige paremaid tulemusi annabki eri meetodite samaaegne kasutamine.

\section{Uurimuse eesmärk ja uurimisküsimused}

Kaasava hariduse põhimõtte järgi peab õpetaja arvestama õppeprotsessis õpilaste erivajadustega. Erivajadustega laste õpetamisel on peale erialaste teadmiste määravaks teguriks õpetaja arusaamad ja hoiakud, mis peegeldavad tema uskumusi (Abu-Hamour \& Muhaidat, 2013; Norwich, 2002), ning kogemused, mis juhivad professionaalset käitumist (Vaughn, Klingner, \& Hughes, 2000). Erivajaduste teema vähene osa õpetajakoolituse õppekavades mõjutab negatiivselt tulevaste õpetajate suhtumist kaasavasse haridusse ja erivajadustega õpilastesse (Swain et al., 2012). Mõistes, missugused on üliõpilaste arusaamad erivajadustest ja kogemused selliste õpilastega, saab kujundada süsteemsemalt tulevaste õpetajate positiivseid hoiakuid ning pakkuda neile tõenduspõhiseid meetodeid erivajaduste käsitlemiseks (ibid.). Siinse uurimuse eesmärk on välja selgitada, kuidas kirjeldavad üliõpilased omi teadmisi, arusaamu, emotsioone ja kogemusi seoses eri liiki erivajadustega. Selleks sõnastati järgmised uurimisküsimused.

1. Millised erivajadustega seotud teadmised, arusaamad, emotsioonid ja kogemused avalduvad õpetajaks õppivate üliõpilaste temaatilistes esseedes?

2. Millised erinevused ilmnevad üliõpilaste kirjeldatud teadmiste ja arusaamade, emotsioonide ja kogemuste vahel sõltuvalt erivajaduse liigist?

3. Missugused komplekssed seosed avalduvad erivajaduste liikide ning üliópilaste kirjeldatud teadmiste ja arusaamade, emotsioonide ja kogemuste vahel? 


\section{Metoodika}

Valim

Uuring tehti õpetajakoolituse erivajadusteteemalise õppeaine raames (kestus 7 nädalat), kus osalesid 21 ópetajakoolituse eriala 218 üliõpilast kahest Eesti ülikoolist. Magistriõppe üliõpilasi oli valimis $94 \%$ ning bakalaureuseõppe või avatud ülikooli üliõpilasi kokku 6\%. Bakalaureuseõppe üliõpilased läbisid õpetajakoolituse aineid vabaainetena, avatud ülikoolis õppijatel oli eriala omandatud, kuid nad soovisid saada ülikoolist pedagoogilist haridust. Üliõpilased õppisid järgmistel õpetajaerialadel: võõrkeeled $(N=41)$, loodusained $(N=19)$, matemaatika ja informaatika $(N=18)$, humanitaarained $(N=42)$, kehakultuur $(N=35)$, loovained $(N=57)$ ja kutsepedagoogika $(N=6)$. Üliõpilaste keskmine vanus oli 30,3 aastat $(S D=8,46, \min =21$, $\max =54)$. Soolise jaotuse järgi osales uuringus 185 naist $(84,9 \%)$ ja 33 meest (15,1\%).

\section{Temaatiline essee erivajadustest}

Erivajadusi käsitleva ainekursuse esimeses loengus said üliõpilased ülesande lugeda kuue nädala jooksul läbi üks ilukirjandusteos, mille peategelane oli erivajadusega laps või täiskasvanu. Raamatu võisid üliõpilased valida kas õppejõu pakutute hulgast (17 raamatut) või otsida ise (lisandus 4 raamatut). Üliõpilastele anti võimalus raamatuid valida, et nad saaksid parema ettekujutuse neid huvitavatest erivajadustest. Raamatute maht oli erinev ( $\mathrm{min}=100$ lk, $\max =495 \mathrm{lk}$ ), ilmumisaeg jäi ajavahemikku 1960-2014. Üliõpilaste valikut mõjutas nii raamatu ilmumisaeg, kättesaadavus raamatukogus kui ka huvi raamatu teema vastu. Temaatiliselt jaotusid raamatud seitsmesse erivajaduste alarühma (vt tabel 1).

Tabel 1. Raamatute jaotus erivajaduste järgi

\begin{tabular}{l|c|l}
\multicolumn{1}{c|}{ Temaatika } & $\begin{array}{c}\text { Raamatute arv } \\
(N=21)\end{array}$ & \multicolumn{1}{c}{ Raamatuvaliku näide } \\
\hline 1. Autism & 5 & D. Tammeti „Sündinud sinisel päeval“ \\
\hline 2. Düsleksia & 1 & J. Bjørneboe „, Jonas“ \\
\hline 3. Intellektipuue & 1 & J-L. Fournieri „Issi, kus me lähme ${ }^{\prime \prime}$ \\
\hline 4. Käitumishäire & 3 & L. Shriveri „Me peame rääkima Kevinist“ \\
\hline 5. Meelepuue & 4 & S. Kuusisto „Pimedate planeet" \\
\hline 6. Liikumispuue & 4 & A. Raudkivi „Pilvedesse poodud lind“ \\
\hline 7. Haigus & 3 & P. Pohla "Ma olen ikka teiega“ \\
\hline
\end{tabular}


Samal ajal, kui üliópilased lugesid raamatut, osalesid nad õppetöös. Pärast raamatu läbilugemist tuli selle põhjal kirjutada 1-2-leheküljeline temaatiline essee selle kohta, mis mõtted neil raamatut lugedes tekkisid. Õppejõu antud tööjuhendis rõhutati eraldi, et üliõpilastelt ei oodata raamatu sisukokkuvõtet ega teksti keelelist analüüsi. Esseed arvestati ühe osana eksamitööst (andis eksamil lisapunkte) ning üliõpilased esitasid selle e-õpikeskkonnas Moodle.

Üliõpilaste esseede esialgsesse analüüsi võeti 218 kirjutist, mille kogumaht oli 523,5 lk ( $1 \mathrm{lk}=1800$ tähemärki koos tühikutega). Esseede keskmine pikkus oli 2,4 lehekülge $(M=2,4, S D=0,8, \min =1, \max =5,2)$. Pärast esmast analüüsi jäeti välja 13 esseed, kuna neis sisaldunud info ei olnud kooskõlas uuringu eesmärgiga või ei võimaldanud vastata kõikidele uurimisküsimustele (nt üliõpilane tegi raamatust sisukokkuvõtte, kirjutis ei vastanud tööjuhendile). Analüüsitud esseede lõplik arv oli 195.

\section{Esseede analiüs}

Esseesid analüüsiti kahes etapis. Esimeses etapis kasutati induktiivsele sisuanalüüsile omast kategooriate loomist (Schreier, 2012). Selleks luges teine autor kõigepealt esseesid ja märkis eri värvidega ära analüüsiühikuks valitavad andmelõigud - tähenduslikud fraasid, üksikud laused või lausete kogumid -, mis sisaldasid üliõpilaste mõtteid erivajaduste kohta ja väljendasid mõistelist tervikut. Seejärel lugesid mõlemad autorid esseesid uuesti, jälgides nii märgistatud lõike kui ka konteksti, ning kirjutasid välja esmased tähenduslikud tekstiühikud üliõpilaste erialaste ja praktiliste teadmiste, arvamuste, erinevate emotsioonide ning kogemuste kohta (vt lisa 1). Pärast paari essee läbitöötamist arutasid autorid esmase kodeerimise tulemusi, toetudes teooriale, ning täpsustasid valitud koode. Mitmekordse esseede lugemise ja arutelude tulemusel liideti sarnase sisuga koodid. Kui alguses oli koode kokku 103, siis analüüsi käigus vähenes nende arv 37-le. Seejärel liigitati koodid alamkategooriatesse (igaühes 5-17 koodi). Et suurendada uurimistulemuste usaldusväärsust, analüüsisid kaks autorit järgnevalt teineteisest sõltumatult üliõpilaste esseesid (vt ka Bazeley, 2013).

Üliõpilaste esseede sisuliste kokkulangevuste põhjal kujunes neli peakategooriat. Esimesse kategooriasse „Teadmised erivajadustest“ liigitati erivajaduste tunnused ning spetsialistide ja sekkumise võimalused. Teise kategooriasse "Arusaamad erivajadustest" rühmitati isiklikud arvamused ja oletused selle kohta, kuidas suhtutakse erivajadustesse, hinnangud spetsialistide tegevusele ning erivajadusega inimese ja/või tema vanemate arvamused olukorra kohta (vt ka Richardson, 1996). Kolmandasse kategooriasse „Erivajadustega seotud emotsioonid" määrati üliõpilaste kirjeldatud positiivsed ja negatiivsed tunded, 
mis tekkisid raamatut lugedes või teemaga seoses laiemalt. Neljas kategooria „Kogemused erivajadusega“ hõlmas samastumist erivajadusega ning kokkupuuteid inimestega, kellel on erivajadus. Täpsem ülevaade esseedes sisaldunud pea- ja alamkategooriatest on esitatud lisas 2.

Teises kodeerimisetapis koostati Exceli andmetabel, kus koodid rühmitati alamkategooriatesse ja need omakorda peakategooriatesse. Seejärel täideti uuringus osalenud üliõpilaste kohta andmetabel, kus nende esseedes kirjeldatud teadmised, arusaamad, emotsioonid ja kogemused kodeeriti dihhotoomselt: 1 - tekstis avaldunud kood; 0 - tekstis puudunud kood. Igale üliópilasele arvutati koodide ja alamkategooriate põhjal nelja peakategooria koondskoorid $(\min =2, \max =15)$, mida kasutatakse järgnevates muutuja- ja indiviiditasandi analüüsides (vt Kline, 2005).

\section{Statistilise andmeanalüïsi meetodid}

Uuringus kasutatud muutujakesksed analüüsid võimaldasid võrrelda õpetajakoolituse üliõpilaste kirjeldatud teadmisi, arusaamu, emotsioone ja kogemusi eeldusel, et valim on homogeenne. Seejuures võisid individuaalsed erinevused jääda väljendumata (Cohen, Manion, \& Morrison, 2007). Indiviidikesksete analüüside puhul toetuti eeldusele, et valimis võivad esineda alarühmad, mille vahel on olulised erinevused (Bergman, Magnusson, \& El-Khouri, 2003; Bergman \& Wångby, 2014).

Kasutades statistikapaketi SPSS Statistics versiooni 24.0, toodi välja üliõpilaste esseedes kirjeldatud erivajaduste kohaste teadmiste, arusaamade, emotsioonide ja kogemuste kirjeldav statistika. Seejärel analüüsiti üliõpilaste kirjelduste erinevusi erivajaduste liikide kaupa, kasutades mitteparameetrilist Kruskali-Wallise testi. Rühmitavaks tunnuseks määrati üliõpilase valitud erivajaduse liik. Paariti post-hoc-analüüsi tegemiseks kasutati Manni-Whitney U-testi. Komplekssete seoste uurimisel rakendati SLEIPNER 2.1 statistikatarkvara paketti kuuluvat konfiguratsioonilist sagedusanalüüsi (KSA) (CFA versiooni 2000; vt von Eye, 2000). KSA võimaldab andmeid üldistamata välja selgitada mustreid, kus teatud tunnuste kombinatsiooniga juhtusid esineb kogu valimis oluliselt sagedamini, kui võiks esineda juhuslikult (tüüp), või esineb neid harvemini, kui võiks baasmudeli alusel oletada (antitüüp) (Bergman et al., 2003; Bergman \& Wångby, 2014; von Eye, 2000). Mustrite hindamiseks võrreldakse kõikides üliõpilaste esseedes kirjeldatud juhtude (ingl observed frequency, $f o$ ) ja oodatud juhtude (ingl expected frequency, $f e$ ) suhet. Seoseid üliõpilaste kirjeldatud erivajaduste ning teadmiste, arusaamade, emotsioonide ja kogemuste vahel analüüsitakse esimest liiki Pearsoni $\chi^{2}$-testiga (von Eye, 2000). 


\section{Tulemused}

\section{Üliõpilaste teadmised, arusaamad, emotsioonid ja kogemused erivajaduste kohta}

Et selgitada välja üliõpilaste temaatilistes esseedes avaldunud teadmised, arusaamad, emotsioonid ja kogemused erivajaduste liikide kaupa, toodi esmalt välja kirjeldav statistika: kirjeldamisel kasutatud keskmine alamkategooriate arv $(M)$ ning miinimumtulemus (min) ja maksimumtulemus (max) seitsme erivajaduste liigi kohta (vt tabel 2). Selgus, et kõige rohkem erinevaid alamkategooriaid kasutati arusaamade kirjeldamisel. Teine huvitav tulemus ilmnes kogemuste kirjeldustes. Nimelt oli osalejate hulgas neid, kellel oli olnud kokkupuude mõne erivajadusega kas tööalaselt või isiklikult (nt üliõpilane oli õpetanud või kasvatas erivajadusega last). Enamikul üliõpilastest selline kokkupuude siiski puudus.

Tabel 2. Esseedes kirjeldatud kategooriad erivajaduste liikide kaupa

\begin{tabular}{|c|c|c|c|c|c|c|c|c|c|c|c|c|c|c|c|c|c|}
\hline \multirow{3}{*}{$\begin{array}{l}\text { Erivajaduse } \\
\text { liik }\end{array}$} & \multicolumn{17}{|c|}{ Üliõpilased $(N=195)$} \\
\hline & \multicolumn{5}{|c|}{ Teadmised } & \multicolumn{4}{|c|}{ Arusaamad } & \multicolumn{4}{|c|}{ Emotsioonid } & \multicolumn{4}{|c|}{ Kogemused } \\
\hline & $N$ & $n$ & $M$ & $\min$ & $\max$ & $n$ & $M$ & $\min$ & $\max$ & $n$ & $M$ & $\min$ & $\max$ & $n$ & $M$ & $\min$ & $\max$ \\
\hline 1. Autism & 42 & 33 & 1,58 & 0 & 4 & 29 & 2,17 & 0 & 4 & 31 & 1,48 & 0 & 4 & 24 & 1,29 & 0 & 3 \\
\hline 2. Düsleksia & 17 & 13 & 1,85 & 0 & 4 & 11 & 2,18 & 0 & 7 & 15 & 1,93 & 0 & 5 & 8 & 1,00 & 0 & 1 \\
\hline $\begin{array}{l}\text { 3. Intellekti- } \\
\text { puue }\end{array}$ & 5 & 1 & 3,00 & 0 & 3 & 4 & 4,75 & 0 & 6 & 5 & 1,60 & 0 & 3 & 2 & 1,00 & 0 & 1 \\
\hline $\begin{array}{l}\text { 4. Käitumis- } \\
\text { häire }\end{array}$ & 23 & 16 & 1,38 & 0 & 3 & 12 & 1,75 & 0 & 4 & 18 & 1,61 & 0 & 4 & 13 & 1,00 & 0 & 1 \\
\hline 5. Meelepuue & 39 & 23 & 2,39 & 0 & 6 & 31 & 2,45 & 0 & 6 & 29 & 2,00 & 0 & 4 & 21 & 1,19 & 0 & 3 \\
\hline $\begin{array}{l}\text { 6. Liikumis- } \\
\text { puue }\end{array}$ & 48 & 25 & 1,64 & 0 & 5 & 46 & 3,54 & 0 & 8 & 43 & 2,00 & 0 & 4 & 30 & 1,53 & 0 & 4 \\
\hline 7. Haigus & 21 & 4 & 1,25 & 0 & 2 & 16 & 2,81 & 0 & 8 & 20 & 1,70 & 0 & 3 & 12 & 1,42 & 0 & 2 \\
\hline
\end{tabular}

Märkus. $N$ - erivajaduse liiki kirjeldanud üliõpilaste üldarv, $n$ - kategooriat kirjeldanud üliõpilaste arv, $M$ - keskmine alamkategooriate arv.

Et analüüsida erinevusi üliõpilaste kirjeldatud teadmiste ja arusaamade, emotsioonide ja kogemuste vahel erivajaduste liikide kaupa, kasutati mitteparameetrilist Kruskali-Wallise testi. Statistiliselt olulised erinevused avaldusid üliõpilaste kirjeldatud arusaamade vahel $\left(\chi^{2}=22,47, d f=6, p<0,001\right)$. Paariti post-hoc-võrdlusest Manni-Whitney U-testiga ilmnes, et intellektipuuet kirjeldanud üliópilased avaldasid oma arusaamu oluliselt mitmekülgsemalt 
võrreldes käitumishäireid $(U=4,00, z=-2,51, p=0,011)$, autismi $(U=14,50$, $z=-2,49, p=0,013)$, meelepuudeid $(U=20,00, z=-2,24, p=0,025)$ ja düsleksiat kirjeldanud üliõpilastega $(U=7,00, z=-2,07, p=0,039)$. Samasuunalised erinevused üliõpilaste kirjeldatud arusaamades ilmnesid liikumispuude ja teiste erivajaduste vahel: liikumispuudeid kirjeldati statistiliselt olulisel määral mitmekesisemalt kui autismi ( $U=388,50, z=-3,09, p=0,002)$, käitumishäireid $(U=120,00, z=-3,05, p=0,002)$, meelepuudeid $(U=478,50$, $z=-2,48, p=0,013)$ ja düsleksiat $(U=139,00, z=-2,34, p=0,019)$.

Teine statistiliselt oluline erinevus erivajaduste kirjelduste vahel ilmnes üliõpilaste kogemuste võrdluses $\left(\chi^{2}=15,61, d f=6, p=0,016\right)$. Isiklikke kogemusi väljendanud üliõpilastest kirjeldas erivajadust kaudselt 26,2\% (nt raamatutegelane või erivajadusega inimene tänaval). Peaaegu $14 \%$ üliõpilastest kirjeldas kogemust mõne lähedase inimese erivajaduse kaudu (nt kasvatas erivajadusega last). Võrdne hulk üliõpilasi (9,7\%) kirjeldas isiklikku kokkupuudet töö- või õpingukaaslase erivajaduse kaudu või oli üliõpilane õpetanud erivajadusega last. Täpsustavast paariti võrdlusest Manni-Whitney U-testiga seitsme erivajaduste liigi vahel selgus, et käitumishäiret kirjeldanud üliõpilased jagasid oma kogemusi oluliselt ühekülgsemalt kui liikumispuuet $(U=110,50$, $z=-2,79, p=0,005)$ või haigusest põhjustatud erivajadust kirjeldanud üliõpilased $(U=45,50, z=-2,55, p=0,011)$. Piiripealne erinevus kogemuste kirjeldustes avaldus ka käitumishäirete ja autismi võrdluses $(U=117,00, z=-1,94$, $p=0,053)$, st autismiga seotud kogemusi kirjeldasid üliõpilased mõnevõrra erilaadsemalt. Oluliselt rohkem oli olnud üliõpilastel kogemusi aga liikumispuuetega kui meelepuuetega $(U=226,50, z=-2,08, p=0,037)$. Lisaks kirjeldasid üliõpilased kogemusi liikumispuudega või haigustest põhjustatud puudega mitmekülgsemalt kui kokkupuuteid düsleksiaga (vastavalt $U=68,00, z=-2,24$, $p=0,025$ liikumispuude ja $U=28,00, z=-2,06, p=0,040$ haiguse kohta). Üliõpilaste teadmiste ja emotsioonide kirjeldustes rühma keskmiste tulemuste tasandil statistiliselt olulisi erinevusi siiski ei leitud.

\section{Teadmiste, arusaamade, emotsioonide ja kogemuste seosed erivajaduste liikidega}

Eespool selgus, et üliõpilaste esseedes kirjeldatud arusaamad ja kogemused erivajadustega erinesid rühma keskmise tulemuse tasandil. Et leida mustreid, kuidas teadmiste, arusaamade, emotsioonide ja kogemuste kirjeldused seostuvad seitsme erivajaduste liigiga, tehti Pearsoni $\chi^{2}$-testiga esimest järku KSA analüüs. Selleks jaotati üliõpilased kirjelduste sageduste standardiseeritud skoori põhjal kolme kategooriasse: $Z>0,5$ - kõrge tase, $-0,5<Z<0,5$ - keskmine tase, $Z<-0,5$ - madal tase. Arusaamu erivajaduste kohta avaldas enamik üliõpilasi 
ja nad jagunesid tasemerühmadesse üsna võrdselt $(22,6-29,7 \%)$. Seevastu kogemusi erivajadustega kirjeldas veidi üle poole üliõpilaste valimist $(56,4 \%)$. Lisaks ei ilmnenud sellist rühma, kelle kogemuste kirjeldused oleksid olnud keskmisel tasemel.

Mustrite analüüsist erivajaduste liikide kaupa eristus neli tüüpilist kombinatsiooni ja üks ebatüüpiline kombinatsioon. Üliõpilasi, kes kirjeldasid oma arusaamu düsleksiast ühekülgselt, esines valimis rohkem, kui oleks võinud oodata juhuslikult $\left(\chi^{2}=5,46, p=0,019, f o=7, f e=2,97\right)$. Oodatust rohkem oli ka selliseid üliõpilasi, kes kirjeldasid mitmekesiselt oma arusaamu liikumispuudest $\left(\chi^{2}=5,30, p=0,021, f o=23, f e=14,30\right)$. Uurides üliõpilaste kogemuste seoseid erivajaduste liikidega, selgus, et oodatust rohkem oli selliseid üliõpilasi, kellel oli erilaadseid kogemusi liikumispuuetega $\left(\chi^{2}=4,31, p=0,038, f_{o}=13\right.$, $f e=7,36$ ). Rohkem kokkupuuteid liikumispuuetega pakkus seega üliõpilastele ainest selle erivajaduse mitmekesisemaks kirjeldamiseks. Otsides mustreid erivajadustega seotud emotsioonide kirjeldustes, leiti huvitav tulemus autismi kohta. Nimelt, kui rühma keskmiste tulemuste võrdlemisel üliõpilaste emotsioonide kirjeldustes olulisi erinevusi ei esinenud, siis KSA analüüsiga ilmnes üks tüüpiline ja üks ebatüüpiline kombinatsioon. Oodatust oluliselt rohkem oli selliseid üliõpilasi, kes kirjeldasid autismiga seotud emotsioone vähesel hulgal $\left(\chi^{2}=8,80, p=0,003, f o=18, f e=9,07\right)$, ja oodatust vähem selliseid üliõpilasi, kes kirjeldasid autismiga seotud emotsioone keskmisel määral $\left(\chi^{2}=5,34\right.$, $p=0,021, f o=1,0, f e=7,20)$.

\section{Arutelu}

Selgitamaks välja tulevaste õpetajate teadlikkuse ja arusaamad erivajadustega laste kaasamisest õppeprotsessi ning nende hoiakud erivajaduste suhtes, analüüsiti, kuidas õpetajakoolituse üliõpilased kirjeldavad temaatilistes esseedes oma teadmisi ja arusaamu, emotsioone ja kogemusi seoses eri liiki erivajadustega. Kasutades muutujakeskseid analüüse, leiti, et üliõpilased avaldasid kõige erilaadsemalt arusaamu intellekti- ja liikumispuuetest ning kirjeldasid kõige ühekülgsemalt kogemusi käitumishäirete ja düsleksiaga. Indiviiditasandi analüüsidest ilmnes, et rohkem kokkupuuteid liikumispuuetega pakkus üliõpilastele ainest selle erivajaduse mitmekesisemaks kirjeldamiseks. Oodatust rohkem oli aga selliseid üliõpilasi, kes väljendasid vähem emotsioone autismi kohta.

Esmalt otsiti vastust uurimisküsimusele, millised erivajadustega seotud teadmised, arusaamad, emotsioonid ja kogemused avalduvad õpetajakoolituse üliõpilaste temaatilistes esseedes pärast erivajadusi käsitlevate ilukirjandusteoste läbilugemist. Selgus, et kõikide erivajaduste kohta väljendasid üliõpilased 
kõige mitmekesisemalt oma arvamust ja arusaamu, seevastu kogemusi kirjeldati oluliselt vähem. Kuna essee juhendis kogemuste kirjeldamist ei nõutud, on võimalik, et osa üliõpilasi ei toonud oma kogemusi erivajadustega essees välja (kogemusi kirjeldas 56,4\% üliõpilastest). Kogemuste vähene kirjeldamine võis olla tingitud ka sellest, et osa erivajadusi on nähtamatud (Carter \& Spencer, 2006). Nii näiteks ei saa inimesele otsa vaadates öelda, kas tal on õpi- või käitumisraskused, küll aga paistab välja liikumispuue. Samas olid üliõpilaste kogemused erivajadustega erinevad: oli neid, kelle kokkupuude jäi kaudseks (nt oli nähtud mõnda telesaadet või kohatud erivajadusega inimest tänaval), ja neid, kes olid mõne erivajadusega ise kokku puutunud (nt erivajadusega inimene on üliõpilase pereliige). Kuna võimalus erivajadusega kokku puutuda mõjutab arusaamade kujunemist (vt Kagan, 1992) ja osal üliõpilastest kogemusi erivajadusega ei olnud, siis siit võivadki tuleneda erilaadsed arusaamad ja nende väljendamisel kasutatud alamkategooriate erinev arv. Teine põhjus, miks üliõpilased oma arusaamu väga erinevalt kirjeldasid, võib olla see, et arusaamad on personaalsed (Greca \& Moreira, 2000) ning kujunevad tahtmatult ja teadvustamatult eelnevate teadmiste ja kogemuste koosmõjul (Kagan, 1992).

Teiseks huvitas meid, millised erinevused ilmnevad üliõpilaste kirjeldatud teadmiste, arusaamade, emotsioonide ja kogemuste vahel sõltuvalt erivajaduse liigist. Üliõpilaste kirjeldatud teadmiste vahel statistiliselt olulisi erinevusi ei leitud. Samuti ei leitud erinevusi erivajaduste kirjeldamisel avaldatud emotsioonide vahel. Erinevused ilmnesid aga üliõpilaste arusaamade ja kogemuste kirjeldustes. Kõikide teiste erivajaduste liikidega võrreldes väljendati mitmekesisemalt arusaamu intellekti- ja liikumispuuete kohta. Raske intellekti- ja liikumispuue on selgete tunnustega (Kirk et al., 2003), mistõttu on nende tuvastamine võrreldes teiste erivajadustega lihtsam. See võis olla ka põhjus, miks üliõpilased kirjeldasid rohkem oma arusaamu just nendest erivajadustest. Mõnevõrra üllatav oli aga tulemus, et õpetajakoolituse üliõpilased esitasid ühekülgsemaid arvamusi nii autismi ja düsleksia kui ka intellekti- ja liikumispuuete kohta. Arusaamade kirjelduste mitmekülgsust võis mõjutada loetud raamatute sisu. Õpiraskustega seotud raamatutes kirjeldati pigem nende erivajaduste kergemaid vorme ja käsitleti erivajadustega ette tulevaid raskusi, kuid kokkuvõttes lõppesid olukorrad positiivselt. Intellekti- ja liikumispuuet kirjeldavates raamatutes kirjeldati aga raskemat puuet ja sellega hakkama saamist. Kuigi need raamatud olid kirjutatud üldjoontes positiivses võtmes, lõppes osa neist puudega inimese surmaga. Kuna negatiivse lõpuga teoseid, nt peategelase haiguse süvenemine ja/või surm, on emotsionaalselt raskem lugeda, tekitasid need arvatavasti just seetõttu erinevamaid arvamusi, mida essees esitada.

Üliõpilaste esseedes avaldunud kogemuste võrdlusest selgus, et kokkupuuteid käitumishäiretega kirjeldasid üliõpilased oluliselt vähem kui kogemusi 
autismi ja kehapuuetega, nt füüsilise liikumispuude ja vähist põhjustatud erivajadusega. Üks põhjus võib olla see, et käitumishäire on nn nähtamatu erivajadus ja selle diagnoosimine vajab pikemaajalisi uuringuid. Teiseks, käitumishäires ei nähta sageli mitte erivajadust, vaid taunitavat hälbivat käitumist ning seetõttu ei tunta seda erivajadust lihtsasti ära (vt Carter \& Spencer, 2006). Autismispektrihäirega lapsed käituvad aga oma erivajadusest tingituna teistest lastest sageli erinevalt (nt teevad kummalisi liigutusi või häälitsusi) ning kehapuudeid kui nähtavaid erivajadusi on lihtsam tuvastada (nt ratastoolis inimest oli kohanud enamik praeguse uuringu üliõpilastest). Haigustega, eriti vähiga, on samuti kokku puutunud ilmselt väga paljud üliõpilased, kuna vähk on üks enim levinud surma põhjuseid (Eurostat, 2016). Seetõttu võib olla peaaegu igaühel mõni tuttav või sugulane, kes on seda haigust põdenud. Lisaks väljendati rohkem kogemusi kehapuuetega kui kokkupuudet düsleksiaga, mis on üks enim tuntud hariduslik erivajadus tavakoolis (Kallaste, 2016). Ilmselgelt on kogenematul inimesel raske tuvastada, kas mõni tema kunagine klassikaaslane oli düsleksiaga või mitte, rääkimata sellest, et üliõpilane ei pruugi olla kokku puutunud selle erivajadusega. Düsleksia kindlaks tegemine nõuab teadmisi tunnustest ja avaldumisest (Black, 2004), kuid neid teadmisi ei ole üliõpilastel enne õpingute läbimist peaaegu üldse ja need ei pruugi olla kõige paremad ka pärast ainekursuste läbimist (Washburn, Binks-Cantrell, \& Joshi, 2014).

Järgnevalt otsiti erivajadusi käsitlevatest esseedest mustreid üliõpilaste kirjeldatud teadmiste, arusaamade, emotsioonide ja kogemuste kohta. Mustrite väljaselgitamiseks kasutati konfiguratsioonilist sagedusanalüüsi (KSA; von Eye, 2000), millega leiti neli tüüpilist ja üks ebatüüpiline kombinatsioon. Oodatust oluliselt rohkem oli selliseid üliõpilasi, kes kirjeldasid oma arusaamu düsleksiast vähe ja ühelaadselt ning liikumispuudest mitmekesisemalt. Liikumispuude korral väljendasid üliõpilased oodatust rohkem ka isiklikke kogemusi. Selline tulemus võib olla seotud asjaoluga, et liikumispuudega inimest kohates tunnevad üliõpilased selle erivajaduse ära, kuid düsleksia inimese välimusest välja ei paista. Järelikult võib rohkem kogemusi erivajadusega pakkuda üliópilastele ainest selle erivajaduse mitmekesisemaks kirjeldamiseks ning annab kindlustunnet oma arusaamade väljendamiseks (Swain et al., 2012).

Huvitav tulemus ilmnes ka üliõpilaste emotsioonide analüüsimisel. Rühma keskmiste tulemuste tasandil ei leitud olulisi erinevusi kirjeldatud emotsioonide mitmekesisuses. KSA analüüs tõi aga autismiga seotud emotsioonide kohta välja kaks olulist kombinatsiooni. Oodatust rohkem oli selliseid üliõpilasi, kes kirjeldasid ühekülgselt autismiga seotud emotsioone, ja oodatust vähem selliseid üliõpilasi, kes kirjeldasid oma emotsioone erilaadselt. Emotsioonide teke võib olla seotud teadmiste vähesuse ja isikliku kogemuse puudumisega (Kikas \& Timoštšuk, 2016; Sharma et al., 2006; Swain et al., 2012). Varasemad uurin- 
gud (Mavropoulou \& Padeliadu, 2000; Toran et al., 2016) näitavad, et ópetajaks õppivad üliõpilased teavad pigem autismi üksikuid tunnuseid, kuid mitte selle erivajaduse kompleksset olemust. Siit võibki tulla erinevus: kui üliõpilased on autismiga kokku puutunud ja neil on paremad teadmised selle erivajaduse kohta, võivad nad väljendada oma emotsioone vähemal määral kui need, kellel kogemus ja teadmised puuduvad.

\section{Piirangud ja järeldused}

Kui teadmiste, arusaamade, emotsioonide ja kogemuste uurimisel kasutatakse enamasti kirjalikku ankeeti või poolstruktureeritud intervjuud, siis praeguses uurimuses rakendati haruldasemat andmekogumisviisi - temaatilist esseed. Seejuures ilmnesid mõned metoodilised piirangud. Selgus, et essee vorm ei sobinud hästi üliõpilaste teadmiste väljaselgitamiseks, sest teadmised erivajadustest ei eristunud esseedes selgesti ning üliõpilaste teadmiste lahushoidmisel arusaamadest tekkis autoritel mõnikord probleeme (vt ka Vuran, 2014). Samuti keskendus osa üliõpilasi temaatilistes esseedes pigem üht tüüpi arusaamade kirjeldamisele. Kuna kodeerimissüsteemi loomisel võeti aluseks aga kirjelduste mitmekesisus, siis esseedes avaldunud korduvused ja detailid uuringu tulemustes ei kajastu. Lisaks võimaldasid kasutatud analüüsimeetodid (mitteparameetriline eristamine ja konfiguratsioonide sagedusanalüüs) võrrelda kirjeldatud teadmiste, arusaamade, emotsioonide ja kogemuste mitmekesisust, kuid ei võimaldanud välja tuua nende põhjuseid.

Kuna uurimuse valim oli mitmekihiline (21 õppekava üliópilased) ja analüüsitud tekstide maht suur (> 500 lehekülge), jäid fookusest välja üliõpilaste taustandmete ja õppekava spetsiifikaga seotud tegurid, nt õppekavarühm, õppeaja kestus, õppeaste. Valimi piirang seostub ka selle esinduslikkusega. Kuna uuringusse kaasati kahe ülikooli üliõpilased ja välja jäi üks suuremaid ülikoole, kus valmistatakse õpetajaid ette, siis ei ole valim (hoolimata selle suurusest) ammendav, et tuua üldistavalt välja erivajaduste temaatikaga seotud kitsaskohad Eesti õpetajakoolituses.

Uurimuse tugevuseks võib pidada analüüsitud temaatiliste esseede suurt hulka $(N=195)$, mida autorid kodeerisid induktiivse sisuanalüüsi spetsiifikat ja kategooriate moodustamise põhimõtteid järgides (Schreier, 2012). Samuti kasutati analüüsimisel erinevaid statistilise andmeanalüüsi meetodeid, mis võimaldasid saada õpetajakoolituse üliõpilaste kohta lisainfot (Bergman \& Wångby, 2014) ning suurendada praeguse uurimuse valiidsust. Uuringu põhjal saab teha mitmeid sisukaid järeldusi ja anda soovitusi.

1. Ilukirjandusteoseid sobib kasutada lisamaterjalina erivajaduste teema käsitlemisel. Raamatud on hea aines erivajaduste kohta arvamuste ja emot- 
sioonide kujundamisel ning kogemuste saamisel (vt ka Ashby, 2012; Kurtts \& Gavigan, 2008; Vuran, 2014).

2. Temaatiline essee on tõhus meetod üliõpilaste arusaamade ja kogemuste uurimiseks ainekursuse alguses. See võimaldab õppetöö käigus muuta ja korrigeerida väärarusaamu.

3. Erivajaduste teema käsitlemisel tuleks keskenduda rohkem nn nähtamatutele ja komplekssetele erivajadustele (nt düsleksia, käitumisraskused), kuna õpetajad ei oska neid hästi tähele panna ega selliseid õpilasi õigesti juhendada.

4. Et kujundada õpetajaeriala üliõpilastel terviklik teadmiste, arusaamade ja kogemuste süsteem seoses eri liiki erivajadustega, võiks teoreetiline kursus erivajaduste kohta olla seostatud praktikaga (vt Swain et al., 2012).

\section{Kasutatud kirjandus}

Abu-Hamour, B., \& Muhaidat, M. (2013). Special education teachers' attitudes toward inclusion of students with autism. The Journal of the International Association of Special Education, 14, 34-40.

Ashby, C. (2012). Disability studies and inclusive teacher preparation: A socially just path for teacher education. Research and Practice for Persons with Severe Disabilities, 37(2), 89-99.

Avramidis, E., Bayliss, P., \& Burden, R. (2000). Student teachers' attitudes towards the inclusion of children with special education needs in the ordinary school. Teaching and Teacher Education, 16(3), 277-293. https://doi.org/10.1016/S0742-051X(99)00062-1

Bazeley, P. (2013). Qualitative data analysis: Practical strategies. London: Sage.

Bergman, L. R., Magnusson, D., \& El-Khouri, B. M. (2003). Studying individual development in an interindividual context: A person-oriented approach. Mahwah, London: Lawrence Erlbaum Associates.

Bergman, L. R., \& Wångby, M. (2014). Indiviidile suunatud käsitlusviis: lühike teoreetiline ja praktiline juhend. Eesti Haridusteaduste Ajakiri, 2(1), 7-28.

https://doi.org/10.12697/eha.2014.2.1.02

Bhatnagar, N., \& Das, A. (2014). Attitudes of secondary regular school teachers toward inclusive education in New Delhi, India: A qualitative study. Exceptionality Education International, 24(2), 17-30.

Black, N. E. (2004). Blessing or curse? Distance delivery to students with invisible disabilities. Journal of Library Administration, 41(1/2), 47-64. https://doi.org/10.1300/J111v41n01_05

Burke, K., \& Sutherland, C. (2004). Attitudes toward inclusion: Knowledge vs. experience. Education, 125(2), 163-172.

Carter, B. B., \& Spencer, V. G. (2006). The fear factor: Bullying and students with disabilities. International Journal of Special Education, 21(1), 11-23.

Cohen, L., Manion, L., \& Morrison, K. (2007). Research methods in education (6th ed.). London, New York: Routledge. 
Čagran, B., \& Schmidt, M. (2011). Attitudes of Slovene teachers towards the inclusion of pupils with different types of special needs in primary school. Educational Studies, 37(2), 171-195. https://doi.org/10.1080/03055698.2010.506319

DeSimone, J. R., \& Parmar, R. S. (2006). Middle school mathematics teachers' beliefs about inclusion of students with learning disabilities. Learning Disabilities Research \& Practice, 21(2), 98-110. https://doi.org/10.1111/j.1540-5826.2006.00210.x

Eha, P. (2010). Oppiabisüsteemide rakendumine ja õpetajate hoiakud Järvamaa põhikoolides (magistritöö). Tartu: Tartu Ülikool. Külastatud aadressil http://dspace.ut.ee/handle/10062/15880.

Eurostat (2016). Surmapõhjuste statistika. Külastatud aadressil http://ec.europa.eu/ eurostat/statistics-explained/index.php/Causes_of_death_statistics/et.

Gafoor, K. A., \& Asaraf, M. P. (2009). Inclusive education: Does the regular teacher education programme make difference in knowledge and attitudes? Paper presented at the International Conference on Education, Research and Innovation for Inclusive Societies, 19-21 March, Dravidian University, Kuppam, Andhra Pradesh, India. Retrieved from http://files.eric.ed.gov/fulltext/ED507434.pdf.

Gehrke, R. S., Cocchiarella, M., Harris, P., \& Puckett, K. (2014). Field experiences and perceptions of inclusion: Varying contexts, structures, and interpretations. Journal of the International Association of Special Education, 15(2), 85-93.

Greca, I. M., \& Moreira, A. M. (2000). Mental models, conceptual models, and modelling. International Journal of Science Education, 22(1), 1-11. https://doi.org/10.1080/095006900289976

Haridus- ja Teadusministeerium (2016). Hariduslike erivajadustega õpilane. Külastatud aadressil https://www.hm.ee/et/tegevused/alus-pohi-ja-keskharidus/hariduslike-erivajadustega-opilane.

Hastings, R. P., \& Oakford, S. (2003). Student teachers' attitudes towards the inclusion of children with special needs. Educational Psychology: An International Journal of Experimental Educational Psychology, 23(1), 87-94. https://doi.org/10.1080/01443410303223

Häidkind, P., \& Oras, K. (2016). Kaasava hariduse mõiste ning õpetaja ees seisvad ülesanded lasteaedades ja esimeses kooliastmes. Eesti Haridusteaduste Ajakiri, 4(2), 60-88. https://doi.org/10.12697/eha.2016.4.2.04

Kagan, D. M. (1992). Professional growth among preservice and beginning teachers. Review of Educational Research, 62(2), 129-169. https://doi.org/10.3102/00346543062002129

Kallaste, E. (2016). Haridusliku erivajadusega ópilaste kaasava hariduskorralduse ja sellega seotud meetmete tõhusus. Temaatiline raport. Eesti Rakendusuuringute Keskus Centar. Külastatud aadressil http://www.centar.ee/uus/wp-content/uploads/2017/01/ Teemaraport-Statistiline-\%C3\%BClevaade-final.pdf.

Kikas, E., \& Timoštšuk, I. (2016). Student teachers' knowledge about children with ADHD and depression and its relations to emotions. Emotional and Behavioural Difficulties, 21(2), 190-204. https://doi.org/10.1080/13632752.2015.1069086

Kirk, S. A., Gallagher, J. J., \& Anastasiow, N. J. (2003). Educating exceptional children. Boston, New York: Houghton Mifflin.

Kline, T. J. B. (2005). Psychological testing: A practical approach to design and evaluation. Thousand Oaks, London, New Delhi: Sage Publications. 
Kurtts, S. A., \& Gavigan, K. W. (2008). Understanding (dis)abilities through children's literature. Education Libraries: Children's Resources, 31(1), 23-31.

Kõrgesaar, J. (2002). Sissejuhatus hariduslike erivajaduste käsitlusse. Tartu: Tartu Ülikooli kirjastus.

Lambe, J. (2007). Northern Ireland student teachers' changing attitudes towards inclusive education during initial teacher training. International Journal of Special Education, 22(1), 59-71.

Levins, T., Bornholt, L., \& Lennon, B. (2005). Teachers' experience, attitudes, feelings and behavioural intentions towards children with special educational needs. Social Psychology of Education, 8(3), 329-343. https://doi.org/10.1007/s11218-005-3020-z

Maanso, V., Erelt, T., Kadakas, M., Kala-Arvisto, U., Kraav, I., Puksand, H., ... Unt, I. (koost.) (2014). Hariduse ja kasvatuse sõnaraamat. Tallinn: Eesti Keele Sihtasutus.

Markova, M., Pit-Ten Cate, I., Krolak-Schwerdt, S., \& Glock, S. (2016). Preservice teachers' attitudes toward inclusion and toward students with special educational needs from different ethnic backgrounds. The Journal of Experimental Education, 84(3), 554-578. https://doi.org/10.1080/00220973.2015.1055317

Mavropoulo, S., \& Padeliadu, S. (2000). Greek teachers' perceptions of autism and implications for educational practice: A preliminary analysis. Autism, 4(2), 173183. https://doi.org/10.1177/1362361300004002005

McAlpine, L. (2016). Miks kasutada narratiivi? Lugu narratiivist. Eesti Haridusteaduste Ajakiri, 4(1), 6-31. https://doi.org/10.12697/eha.2016.4.1.02

Meynert, M. J. (2014). Inclusive education and perceptions of learning facilitators of children with special needs in a school in Sweden. International Journal of Special Education, 29(2), 35-52.

Norwich, B. (2002). Education, inclusion and individual differences: Recognising and resolving dilemmas. British Journal of Educational Studies, 50(4), 482-302. https://doi.org/10.1111/1467-8527.t01-1-00215

Olney, M. F., \& Kim, A. (2001). Beyond adjustment: Integration of cognitive disability into identity. Disability \& Society, 16(4), 563-583. https://doi.org/10.1080/09687590120059540

Põhikooli- ja gümnaasiumiseadus (2010). Riigi Teataja I 2010, 41, 240. Külastatud aadressil https://www.riigiteataja.ee/akt/13332410.

Richardson, V. (1996). The role of attitudes and beliefs in learning to teach. J. Sikula (Ed.), Handbook of research on teacher education (2nd ed., pp. 102-119). New York: McMillan.

Sari, H. (2007). The influence of an in-service teacher training (INSET) programme on attitudes towards inclusion by regular classroom teachers who teach deaf students in primary schools in Turkey. Deafness \& Education International, 9(3), 131-146. https://doi.org/10.1179/146431507790559996

Schreier, M. (2012). Qualitative content analysis in practice. Los Angeles: Sage.

Seepter, K. (2010). Longitudinal study of cognitive influences of peers, teacher's knowledge and parental expectations on pupils' achievement: Impact on low-, averageand high-ability pupils. In Toomela, A. (Ed.), Systemic person-oriented study of child development in early primary school (pp. 25-46). Frankfurt am Main etc.: Peter Lang. 
Shah, R., Das, A. K., Desai, I. P., \& Tiwari, A. (2016). Teachers' concerns about inclusive education in Ahmedabad, India. Journal of Research in Special Educational Needs, 16(1), 34-45. https://doi.org/10.1111/1471-3802.12054

Sharma, U., Forlin, C., Loreman, T., \& Earle, C. (2006). Pre-service teachers' attitudes, concerns and sentiments about inclusive education: An international comparison of the novice pre-service teacher. International Journal of Special Education, 21(2), 80-93.

Specht, J., McGhie-Richmond, D., Loreman, T., Mirenda, P., Bennett, S., Gallagher, T., ... Cloutier, S. (2016). Teaching in inclusive classrooms: Efficacy and beliefs of Canadian preservice teachers. International Journal of Inclusive Education, 20(1), 1-15. https://doi.org/10.1080/13603116.2015.1059501

Swain, K. D., Nordness, P. D., \& Leader-Janssen, E. M. (2012). Changes in preservice teacher attitudes toward inclusion. Preventing School Failure: Alternative Education for Children and Youth, 56(2), 75-81. https://doi.org/10.1080/1045988X.2011.565386

Ting, C., \& Gilmore, L. (2012). Attitudes of preservice teachers towards teaching deaf and ESL students. Australian Journal of Teacher Education, 37(12), 46-56. https://doi.org/10.14221/ajte.2012v37n12.6

Toran, H., Westover, J. M., Sazlina, K., Suziyani, M., \& Mohd Hanafi, M. Y. (2016). The preparation, knowledge and self reported competency of special education teachers regarding students with autism. Pertanika Journal of Social Science and Humanities, 24(1), 185-196.

Vaughn, S., Klingner, J., \& Hughes, M. (2000). Sustainability of research-based practices. Exceptional Children, 66(2), 163-171. https://doi.org/10.1177/001440290006600202

Von Eye, A. (2000). Introduction to configural frequency analysis: The search for types and antitypes in cross-classifications. Cambridge: Cambridge University Press.

Vuran, S. (2014). Stories about children with disabilities: The writing process and the opinions of the storywriters. Eurasian Journal of Educational Research, 55, 137158. https://doi.org/10.14689/ejer.2014.55.9

Washburn, E. K., Binks-Cantrell, \& Joshi, R. M. (2014). What do preservice teachers from the USA and the UK know about dyslexia? Dyslexia, 20(1), 1-18. https://doi.org/10.1002/dys.1459

Übius, Ü., Kall, K., Loogma, K., \& Ümarik, M. (2014). Rahvusvaheline vaade õpetamisele ja õppimisele. OECD rahvusvahelise õpetamise ja õppimise uuringu TALIS 2013 tulemused. Tallinn: SA Innove. Külastatud aadressil http://uuringud.ekk.edu. ee/fileadmin/user_upload/documents/TALIS/TALIS2013_Eesti_raport.pdf. 
Lisa 1. Näiteid esseedest.

\begin{tabular}{|c|c|c|}
\hline Kategooria & Alamkategooria & Tähenduslik tekstiühik \\
\hline \multirow[t]{2}{*}{ Teadmised } & EV tunnused & $\begin{array}{l}\text { Pärilik lihasdüstroofia on pärilik haigus, mille all } \\
\text { kannatavad vaid poisslapsed. Sellel haigusel puudub } \\
\text { ravi ning olenevalt haiguse raskusest on eeldatav } \\
\text { eluiga kuni teismelise eani. (Liikumispuue, M 26) }\end{array}$ \\
\hline & $\begin{array}{l}\text { Õpetamisel } \\
\text { tuleb arvestada } \\
\text { EVga }\end{array}$ & $\begin{array}{l}\text { Raamat aitas mul paremini mõista, et kui kurnav } \\
\text { ja segadusse ajav võib ühe aspergerist lapse jaoks } \\
\text { olla info üleküllus. Sellise lapse õpetamise puhul } \\
\text { tuleb kindlasti arvestada, et ei ôpiks palju uusi asju } \\
\text { korraga, kindlasti tulevad kasuks reeglid tunnis, } \\
\text { midagi, mis on kogu aeg ühtemoodi. Peab arvestama, } \\
\text { et ka muutused nagu tunniplaani muutus, asendus- } \\
\text { õpetaja või klassiruumi vahetus võivad temas liigset } \\
\text { stressi tekitada. (Autismispektrihäire, N 35) }\end{array}$ \\
\hline \multirow[t]{2}{*}{ Arusaamad } & $\begin{array}{l}\text { EV tekitab võõ- } \\
\text { rastust }\end{array}$ & $\begin{array}{l}\text { Paljud inimesed tõrjuvad erivajadustega inimesed } \\
\text { eemale, nad nagu kardaksid neid. (Liikumispuue, } \\
\text { M 33) }\end{array}$ \\
\hline & $\begin{array}{l}\text { Halvustav suh- } \\
\text { tumine ühiskon- } \\
\text { nas }\end{array}$ & $\begin{array}{l}\text { Poisil on düsleksia ehk lugemishäire, mis on kõikide } \\
\text { tema raskuste ja murede allikaks, kuna inimesed } \\
\text { peavad teda 'teiseks' ehk ebasobilikuks ühiskonna } \\
\text { jaoks. (Düsleksia, M 24) }\end{array}$ \\
\hline \multirow[t]{2}{*}{$\begin{array}{l}\text { Emot- } \\
\text { sioonid }\end{array}$} & $\begin{array}{l}\text { Kurbus ja kaas- } \\
\text { tunne }\end{array}$ & $\begin{array}{l}\text { Kõige rohkem tunnen ma sellises situatsioonis } \\
\text { alati kaasa vanematele, kellele on see eriti valus } \\
\text { hoop. Kuidas nende nahas käituda, on võimatu ette } \\
\text { kujutada. (Düsleksia, M 32) }\end{array}$ \\
\hline & Rõõm ja imetlus & $\begin{array}{l}\text { Olen alati imetlenud inimesi, kellel on mingisugune } \\
\text { puue. Nad on enamasti elurõõmsad, tahtejõulised ja } \\
\text { tihti jõuavad veel teisigi aidata. (Meelepuue, N 26) }\end{array}$ \\
\hline \multirow[t]{2}{*}{ Kogemused } & $\begin{array}{l}\text { Samastumine } \\
\text { EVga }\end{array}$ & $\begin{array}{l}\text { Vähi teema on mulle väga lähedane, kuna ise } \\
\text { olen selle läbi põdenud, käisin läbi keemiaravi, } \\
\text { olin kiilakas, võtsin kaalust alla. Õnneks jäin ellu. } \\
\text { (Haigus, N 34) }\end{array}$ \\
\hline & Pereliige EVga & $\begin{array}{l}\text { Mind jääb saatma üks kahetsusväärne lugu, juh- } \\
\text { tus see minu lähisuguseltsis, nimelt, minu noorel } \\
\text { sugulasel oli lapsena palju probleeme kuulmisega, } \\
\text { pidi koolist haiguse tõttu palju puuduma, sellest } \\
\text { tulenevalt oli tal ka koolis raskusi õppimisega. } \\
\text { (Meelepuue, N 32) }\end{array}$ \\
\hline
\end{tabular}

Märkus. EV - erivajadus; sulgudes esitatud info: erivajaduste liik, sugu ( $\mathrm{N}$ - naine, $\mathrm{M}$ - mees), vanus. 
Lisa 2. Intervjuudes ilmnenud kategooriad esinemissageduse järjekorras.

\begin{tabular}{|c|c|c|c|}
\hline Arusaamad & Teadmised & Emotsioonid & Kogemused \\
\hline $\begin{array}{l}\text { Vähesed teadmised } \\
\text { erivajadusest ja } \\
\text { oskamatus aidata }\end{array}$ & $\begin{array}{l}\text { Erivajaduse tunnu- } \\
\text { sed }\end{array}$ & $\begin{array}{l}\text { Kurbus/ } \\
\text { kaastunne }\end{array}$ & $\begin{array}{l}\text { Samastumine } \\
\text { erivajadusega }\end{array}$ \\
\hline Toetav suhtumine & $\begin{array}{l}\text { Erivajadusega } \\
\text { arvestamine } \\
\text { oppetamisel }\end{array}$ & Rõõm/imetlus & Pereliige \\
\hline $\begin{array}{l}\text { Erivajadusega isiku } \\
\text { positiivne hoiak }\end{array}$ & $\begin{array}{l}\text { Erimetoodika } \\
\text { rakendamine }\end{array}$ & Hämming & Võõras inimene \\
\hline $\begin{array}{l}\text { Võõrastus erivajaduse } \\
\text { suhtes }\end{array}$ & Õpetaja/abiõpetaja & Hirm/viha & $\begin{array}{l}\text { Kooli-/ } \\
\text { klassikaaslane }\end{array}$ \\
\hline $\begin{array}{l}\text { Erinemine teistest } \\
\text { inimestest }\end{array}$ & Tugisüsteem & $\begin{array}{l}\text { Positiivne } \\
\text { suhtumine }\end{array}$ & Õpilane \\
\hline Spetsialisti abi & Abivahendid & Vastakad tunded & \\
\hline Hoolivus ühiskonnas & $\begin{array}{l}\text { Erivajaduse } \\
\text { ravimatus }\end{array}$ & Lootusetus & \\
\hline $\begin{array}{l}\text { Erivajadusega isiku } \\
\text { negatiivne hoiak }\end{array}$ & $\begin{array}{l}\text { Spetsialistide } \\
\text { koostöö }\end{array}$ & & \\
\hline \multicolumn{4}{|l|}{$\begin{array}{l}\text { Halvustav suhtumine } \\
\text { ühiskonnas }\end{array}$} \\
\hline \multicolumn{4}{|l|}{$\begin{array}{l}\text { Lapsevanema } \\
\text { toimetulekuraskused }\end{array}$} \\
\hline \multicolumn{4}{|l|}{ Toetav perekond } \\
\hline \multicolumn{4}{|l|}{$\begin{array}{l}\text { Erivajadusega isiku } \\
\text { üksindus/eraldatus }\end{array}$} \\
\hline \multicolumn{4}{|l|}{ Stressis lapsevanem } \\
\hline \multicolumn{4}{|l|}{$\begin{array}{l}\text { Oskus aidata } \\
\text { erivajadusega isikut }\end{array}$} \\
\hline Võõrandumine & & & \\
\hline
\end{tabular}




\title{
The manifestation of student teachers' knowledge, understanding, emotions, and experiences in their essays about special needs
}

\author{
Krista Uibu $^{\text {al }}$, Helin Puksand ${ }^{\mathrm{b}}$ \\ ${ }^{a}$ Institute of Education, University of Tartu \\ ${ }^{b}$ School of Educational Sciences, Tallinn University
}

\section{Summary}

\section{Introduction}

The implementation of inclusive education means there are more children with special educational needs in mainstream classrooms. Therefore, teachers should have knowledge and understanding about special needs and how to deal with them. The lack of knowledge about special needs is one of the biggest problems in Estonian schools (Übius et al., 2014). However, a good knowledge and understanding support the formation of positive attitudes and professional behaviour and form the future teachers' awareness about inclusive education.

Successful engagement relies on the idea that people are different (Vuran, 2014). Therefore, teachers have to know what age-appropriate child development is and which signs indicate special needs. Teachers' attitudes and understanding affect the readiness for inclusion (Abu-Hamour \& Muhaidat, 2013; Norwich, 2002). Teachers who have a positive attitude toward inclusion of students with special needs are able to adapt better to the tasks and the curriculum, taking into account the specific and individual needs of students (Bhatnagar \& Das, 2014; Swain et al., 2012). Knowing student teachers' understanding about special needs and experiences with these, we can develop positive attitudes and provide them with evidence-based methods to teach all students (Swain et al., 2012).

The aim of this study is to investigate how student teachers describe their knowledge, understanding, emotions, and experiences of various special needs. The following three study questions were formulated: 
1. What knowledge, understanding, emotions and experiences are expressed in thematic essays about special needs?

2. What kind of differences emerge in students' descriptions about knowledge and understanding, emotions and experiences according to different types of special needs?

3. What are the typical relations between different types of special needs and students' knowledge, understanding, emotions and experiences?

\section{Method}

Within the framework of the study, 218 student teachers from 21 programmes of two Estonian universities participated in the survey. This article analyses their thematic essays, written on the basis of books about different kind of special needs. According to the topics of the books, seven sub-groups of special needs were differentiated: 1) autism, 2) dyslexia, 3) intellectual disability, 4) behavioural problems, 5) sensory disabilities, 6) physical disability and 7) disease (e.g., cancer). The thematic essays were analysed by using an inductive content analysis (Schreier, 2012), sentences or sets of sentences that expressed a conceptual whole were used as analytic units. Four main categories emerged from the data: 1) knowledge about special needs, 2) understanding connected to special needs, 3) emotions related to special needs, 4) experiences with special needs. By using variable and person-oriented approaches to the data, analyses were employed to provide more comprehensive information (Bergman et al., 2003; Cohen et al., 2007).

\section{Main results and discussion}

It appeared that students described their understanding about intellectual and physical disabilities more multifariously than understanding about dyslexia and autism. However, they were less detailed in their descriptions about experiences with behavioural problems and dyslexia. On the one hand, the formation of understanding is influenced by previous experiences (Kagan, 1992) and that is the reason why students describe their understanding about intellectual and physical disabilities more than behavioural problems and dyslexia. On the other hand, where severe intellectual and physical disabilities are visible; behavioural problems and dyslexia are invisible disabilities (Black, 2004; Carter \& Spencer, 2006). Therefore, students describe their understanding about visible disabilities more variously.

We were also interested in differences in students' knowledge, understanding, emotions and experiences. Contrary to our assumption, differences in students' knowledge and emotions according to the types of special needs were not 
found. The reason might be that the thematic essay about books is not suitable for testing knowledge (see also Vuran, 2014). Continuing from the previous point, the students expressed their understanding about learning difficulties autism and dyslexia - less than concerning intellectual and physical disabilities. Severe intellectual and physical disabilities have very clear signs (Kirk et al., 2003), so their detection is easier as compared to other special needs. This may be the reason why more students expressed their understanding about these special needs more profoundly. Comparing students' experiences with special needs, we found that their contacts with behavioural problems were described significantly superficially in the essays compared to their experiences with autism and physical disabilities. In addition, their experiences with physical disabilities were described in more detail than their contacts with dyslexia.

Additionally, based on person-oriented approach, students' understanding, emotions and experiences were related to the types of special needs. Altogether, by using the configural frequency analysis (CFA version 2000; von Eye, 2000) altogether four types and one antitype were indicated. There were more students than expected by chance who described their understanding about dyslexia more superficially. Furthermore, there were more students than expected by chance who described their understanding about physical disabilities more carefully. As the signs of learning disabilities are often hidden, the teachers did not recognise them (Washburn et al., 2014). Interesting results also appeared when analysing students' emotions about special needs. More students than could be expected by chance described their emotions about autism very modestly. Additionally, less students than expected represented their emotions with autism on the average level. The reason might be that students do not have enough knowledge of autism and experience with it (Mavropoulou \& Padeliadu, 2000; Toran et al., 2016).

The research results allow the following recommendations and implications. First, writing essays is an effective method for finding out about students' understanding, experiences and emotions, but this method is not suitable for the knowledge control. Second, the courses of special needs should focus more on invisible disabilities (e.g., dyslexia, behavioural disability), because otherwise the teachers do not notice them and cannot use the right methods. Third, to develop an entire system of knowledge, understanding, and experiences, the theoretical course of special needs should be related with practice (Swain et al., 2012).

Keywords: teacher training, special needs, understanding, experiences, thematic essay 